\title{
A Study on Developing Groundwater Information System (GWIS) for Sustainable Management of Groundwater Resources-A Case Study from Visakhapatnam Urban Region
}

\author{
B. Kameswara Rao ${ }^{1}$, A, S. N. Chakravarthy ${ }^{2}$, M. Jagannadha Rao ${ }^{3}$, Mustefa Mohammad Seyid ${ }^{4}$, \\ Ch. Ramakrishna ${ }^{5}$ \\ ${ }^{1}$ Department of CSE, JNTUK, Kakinada, India \\ ${ }^{2}$ Department of CSE, JNTUKUCE, Vizianagaram, India \\ ${ }^{3,4}$ Department of Geology, Andhra University, Visakhapatnam, India
}

${ }^{5}$ Department of Environmental Science, GITAM University, Visakhapatnam, India

\begin{abstract}
Groundwater resources are of most essential natural treasure for mankind. In urban areas the population is dependent upon the groundwater for drinking, industrial, and other purposes. The demand for groundwater has been increasing in urban areas because of the fact that the population of urban areas has been increasing day by day. The Visakhapatnam city of Andhra Pradesh is one such city, which is considered as fastest developing urban areas of East coast of India. The city has unique geology and hydrological conditions with the three important aquifer systems. The groundwater resources need to be scientifically monitored for sustainable utilisation. For this purpose, a computer based program called 'Groundwater information system"' (GWIS) has been designed for this city and being proposed in this paper. The information will be able to integrate all aspects related to groundwater occurrence, recharge, monitoring of utilisation, quality assurance, database maintenance, etc. For this purpose, software packages like GIS, will be customised and implemented. The details of the information system has been presented in this paper. It is related to the Visakhapatnam urban area as the case study and the details are discussed.
\end{abstract}

Keywords: Groundwater, Information system, Visakhapatnam, aquifer management, sustainability

\section{Introduction}

The management of Groundwater monitoring and groundwater data acquisition are pre-requisites for any effective management of groundwater resources, in terms of both the groundwater quality and the availability of the groundwater resource itself. Because of the complexities of groundwater systems, the design and operation of an effective groundwater monitoring is far from simple. Yet well-designed monitoring systems are capable of providing vital aquifer information at a reasonable cost. This paper discusses the different purposes and objectives of monitoring for the management of groundwater and how a monitoring system can be designed and operated in an effective way. The underlying principle is that groundwater monitoring should always be target oriented. The management question should be defined first and monitoring can be designed accordingly. In this way, the purpose of monitoring and its results are also better acknowledged by all the stakeholders.

The groundwater monitoring cycle: The purpose oriented approach to groundwater monitoring is also reflected in the monitoring cycle which comprises the complete process of problem definition, management objectives, information needs, data acquisition, data storage, interpretation and dissemination, giving rise to relevant accurate information for aquifer understanding and for consequent management actions. The essence of monitoring includes the design of the monitoring system, and the collection, processing and interpretation of data in order to respond to a suite of welldefined information needs for management purposes. All the steps in the monitoring process should be carefully defined and designed for the specific purpose of the monitoring. Groundwater specialists may tend to put the emphasis on the collection of the data and its interpretation and may give less attention to the dissemination of the results to other stakeholders. Yet the monitoring cycle is only complete if it has provided the required information for managers or water users to take action. For this purpose the "Groundwater Information System” (GWIS) is being proposed.

What is the Ground Water Information System? (GWIS) The Water Management System is a computer system designed to support the water resource management function of DWAF with emphasis on water and environmental quality

The GWIS system consists of three sub-systems:

- WM is used to manage resource quality operational monitoring on a National basis in an effective and efficient manner

- $\mathrm{QM}$ is used to achieve the sustainable use of water and the protection of the quality of the water resource

- Spatial M (GIS) is used to geographically display Water Resource information in order to assist in interpreting and determining the quality and the status of the water resource 


\section{International Journal of Science and Research (IJSR) ISSN (Online): 2319-7064}

Index Copernicus Value (2013): 6.14 | Impact Factor (2015): 6.391

\section{A CASE Study of Visakhapatnam}

The Visakhapatnam city is one of the fastest developing cities in India and located in the East coast India. The population increase in this city is very alarming because people are migrating to this city from rural areas for employment, business etc this is causing severe pressure on natural resources like land, water etc. In this way the ground water resources are under severe threat of depletion due to increasing consumption at the same time the decreasing of recharge potential. This is because of the fact the recharge areas are being converted into residential areas preventing the rainwater entering into the aquifer in the subsurface. The government is having plans to make this city as one of the smart cities of the country and implementing projects for its development in the area such as industry, tourism, education, transportation etc. Under these circumstances "'the groundwater information system will help to manage the groundwater resources in a more scientific and effective manner. This system will help the policy maker by providing data on the following areas. These are

- Data on groundwater resource availability in the three aquifer zones namely Kailasa aquifer, Coastal aquifer and Duvvada aquifer.

- Provide data on the catchment zones and zones of infiltration including the decrease or increase of these areas.

- Provide data on groundwater availability verses consumption of groundwater.
- Provide data on pre-monsoon quality variations and depth fluctuations provide data on levels of industrial pollution.

- Will generate data on the aspect of salt water intrusion.

- The information system will generate automatic report of all the aspects for the benefit of policy maker to take appropriate decision towards groundwater resource conservation.

\section{Location}

\section{Physiography}

The study area is characterized by Eastern Ghats mobile belt. This are covered with denudational hills of range between $30 \mathrm{~m}$ to $594 \mathrm{~m}$ above mean sea level. Kailasa range and Yarada range are two important hill ranges. Kailasa hill range limits the Visakhapatnam city in the northern boundary whereas the Yarada range is located in the southern side. These two ranges are being separated from each other by a vast tidal basin, a few scattered hillocks and portions of low land. The above mentioned two hills range attaining a maximum height of $506 \mathrm{~m}$ and $356 \mathrm{~m}$ respectively are extending nearly east to west, and thus deviate from the general NE-SW trend of Eastern Ghats. These two hill ranges typically end their extremities into the sea as promontories. The Dolphin's nose, one such promontory formed by Yarada range, is famous for its shape similar to the fish Dolphin's Nose (Fig-1).

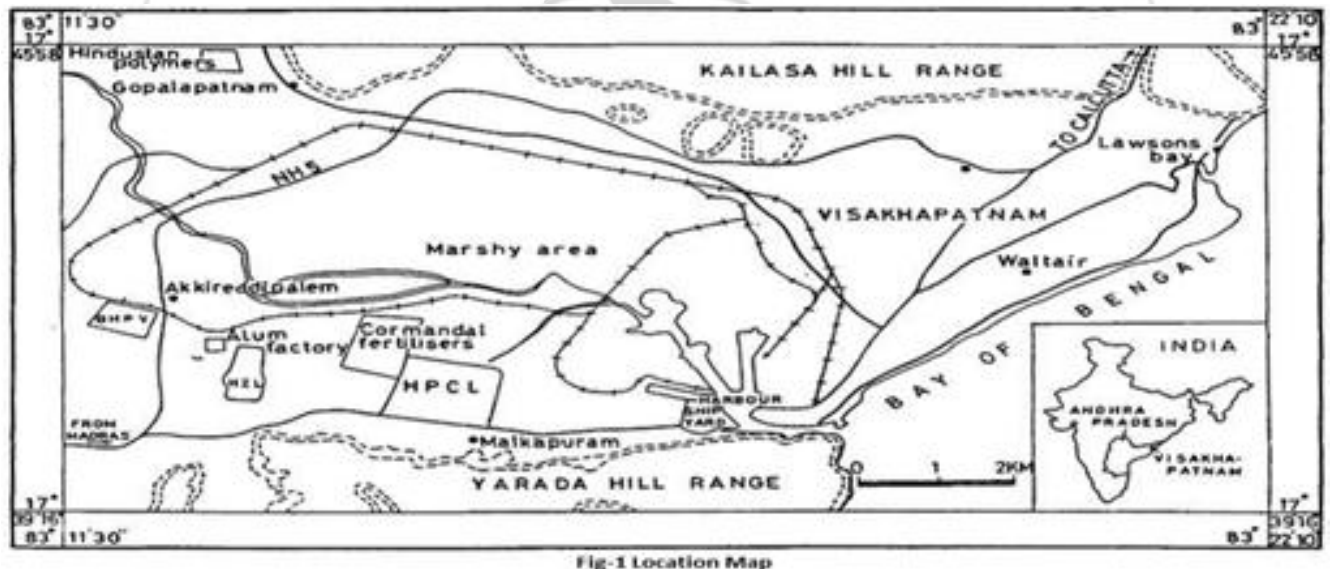

\section{Geology of the Study Area}

The study area geologically belongs to Precambrian age and is characterized by the occurrence of meta-sediments and intrusive meta igneous bodies. Apart from meta sediments the area is also marked by the occurrence of recent sediments such as red sediments with calcium carbonate calcretes, dune sands and beach sands with economically important black sand concentrations. All these rocks and sediments characteristically exhibit a variety of geomorphic features distributed from deepest hinterland to near coastal plains.

King (1886) gave the geological sketch of Visakhapatnam district. Narasimha Rao (1945) studied the geology and petrology of the Kaisala range. Mahadevan and Sathapathi (1949) described the origin of Waltair high lands. Anjeneyulu (1950) studied the geology of the coastal strip between Anakapalle and Vizianagram. Sastry (1952) studied the geology of the western part of the toposheet NO's 65 O/6, O/9; Murthy (1961) studied the structure, mineralogy and petrology of the charnockite series of Visakhapatnam district. Natarajan et.al (1979) studied the geology and its influence on physical environments of Visakhapatnam city and its neighbourhood. Nookaraju and Vaidyanadhan (1971) carried out geomorphological studies. Bhaskara Rao and Vaidyanadhan (1975) studied the coastal features between pudimadaka and Visakhapatnam. Jagannadha Rao et.al (2003, 2013) carried out the studies on coastal Geomorphology of Visakhapatnam and he also studied on geomorphology and land use pattern of Visakhapatnam Urban-Industrial area.

Garnet-sillimanite-biotite

(Khondalites),hypersthenes granites

gneisses garnetiferous granites (Leptynites), quartzites and 


\section{International Journal of Science and Research (IJSR) \\ ISSN (Online): 2319-7064 \\ Index Copernicus Value (2013): 6.14 | Impact Factor (2015): 6.391}

pegmatites are the chief rock types that occur as bedded and banded as well as massive formations in the study area. Natarajan et.al (1979) studied the structures of this area. According to them this area can be classified into a large scale basin coupled with a dome structure near Madhuravada. This area can be termed as Archaean high grade metamorphic migmatite complex of the Eastern Ghat mobile belt.

\section{Hydrogeology of Visakhapatnam City:}

As discussed above the Visakhapatnam is marked by geological formations such as Khondalite,Charnockite, Leptynite and quartzite. However, the most important and most abundant rock type is Khondalite. All the hill ranges which are defining the city in three directions are namely:

1. Kailasa hill range (In the North),

2. Yarada hill range /dolphins nose(In the south) and

3. Duvvada range (In the west)

Whereas the eastern parts of the city is bordered by Bay of Bengal. All the hill ranges are acting like catchment areas and collect rain water which will recharge the aquifer systems of Visakhapatnam. Hydrogeologically, the Visakhapatnam aquifer system can be divided into three subsystems. These are:

1. Kailasa aquifer

2. Coastal aquifer

3. Duvvada aquifer (Marshy aquifer)
Lithologically the rock unit Khondalite forms a good aquifer by way of chemical weathering resulting kaolin and formation of fracture zones which will make the khondalites porous and permeable.

In this way the Visakhapatnam is having good aquifers in the khondalite lithology. The next important rock types are leptynite and charnockite. They are occurring in association with each other and the leptynites are exposed to the surface beneath which the charnockites are occurring. These are occurring like small mounds and exposed at places like Cyclone warning center, GnanaPuram, Governors bunglow, airport, Kurmanna Palem etc

Though exposed as small mounds on surface, these rocks are forming a continuous underground lithological barrier with surface leptynite ans subsurface charnockite and dividing the Khondalitic Kailasa aquifer from coastal aquifer on the south and Duvvada aquifer in the south west. In this way the Kailasa aquifer has unique geomorphological advantage of supersaturated ground water occurrence because of its prevention to move lowe altitudes by the charnockitic barrier (Fig-2) and supplying plenty of water to areas like Isukathato, Seethammadhara, Balayya Sastry Lay out, Murali Nagar etc. In fact sometimes in the post monsoon season the water is oversaturated in this aquifer resulting natural springs in the Kailasa hills which are called Seethamma Dhara, Madhava Dhara, Simha Chalam Temple Springs etc.

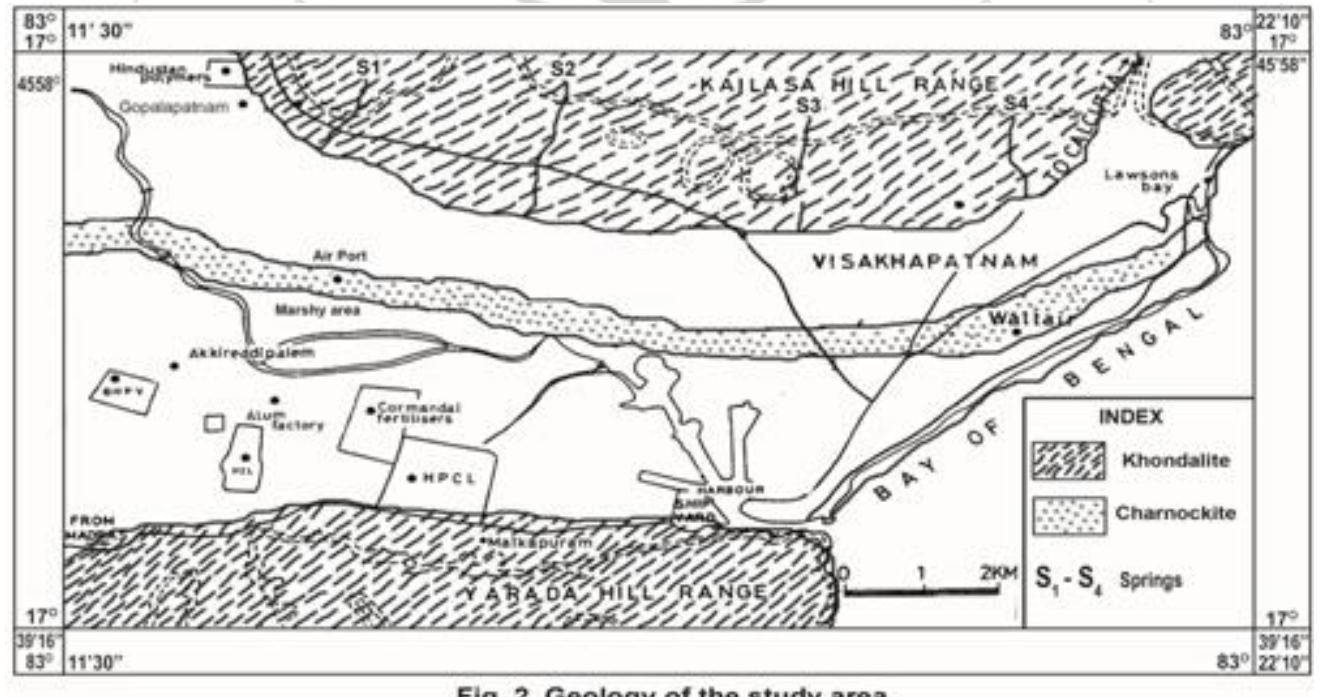

Fig. 2. Geology of the study area

The Coastal aquifer system is next important aquifer which is also formed in khondalite rocks. The areas adjacent to bay of Bengal namely MVP colony, Lawson's Bay, Beach Road, PedaWaltair, ChinnaWaltair, Coastal battery, KGH Area etc. come under this aquifer. Because of rapid urbanization the coastal areas are heavily developed with multi-stored buildings putting a lot of pressure on groundwater resources of coastal aquifer, Because of this, there is increased withdrawal of ground water crossing the optimum limit. This sometimes results in the situation of seawater intrusion at some places and this problem has been observed in areas like Sagar Nagar, Beach Road etc.
The Duvvada aquifer also lithologically made up of khondalite rock type and the groundwater is partially occurring in marshy area and some part in industrial belt. The industrial pollution caused earlier by industries like HZL, Coromondal Fertilisers etc and polluted the ground water in areas like Mindi, BHPV, Gajuwaka, Mulagada, Malkapuram etc (Shyam Kumar, 1995) The groundwater information system GWIS will be having sub system for effective implementation of the whole program. These are:

1) Sub system on monitoring WM

2) Sub system on resource management QM

3) Sub system on spatial functions Spatial M

These three sub systems are shown in the following figures below. (Fig-3-5) 
SUB-SYSTEM - WM

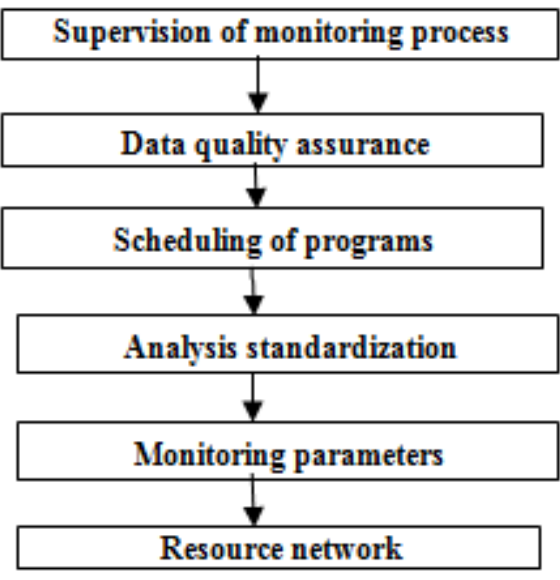

Figure 3: Subsystem-MM
SUB-SYSTEM - QM

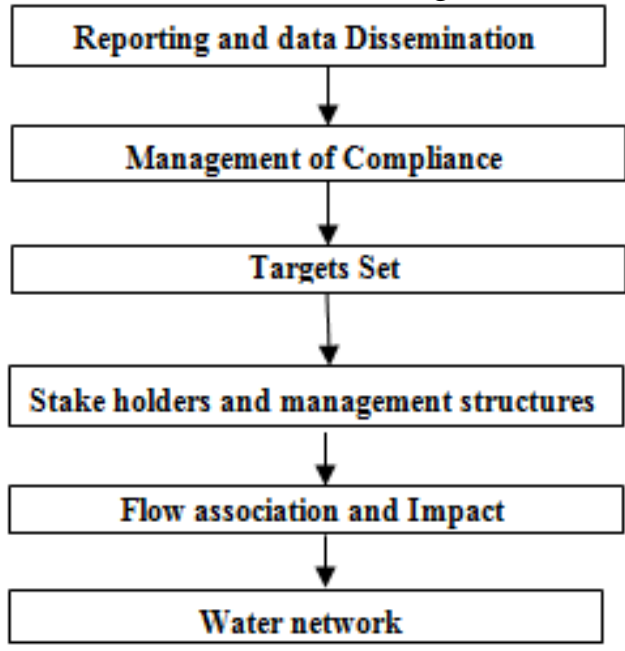

Figure 4: Subsystem-QM

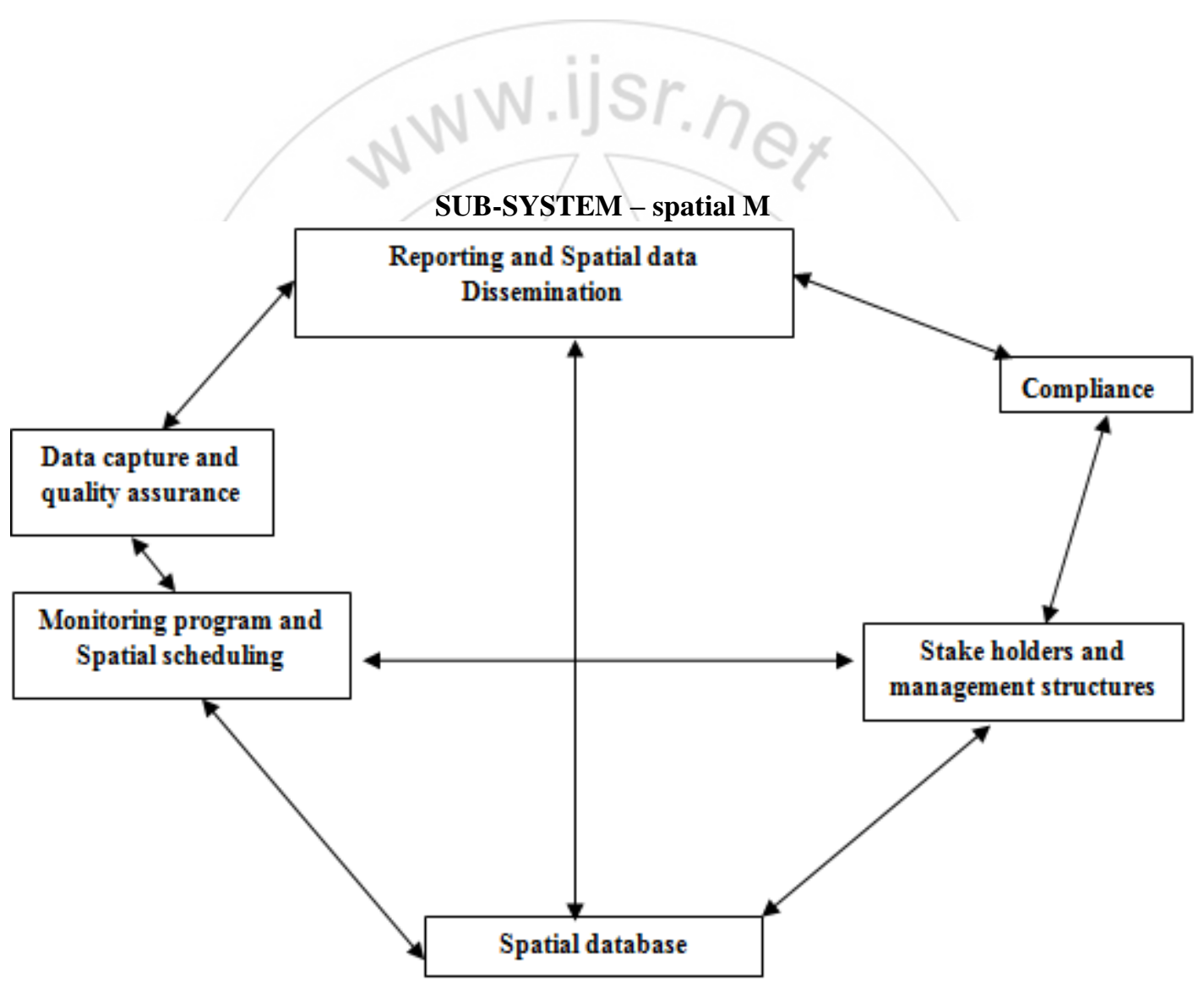

Figure 5: Subsystem-Spatial M

\section{Data Capture Process}

In this process the most important aspect is sample collection, sample registration, followed by sample analysis to generate data on quality parameters to determine the suitability of ground water for human consumption.

The monitoring wells which are identified in all the three aquifer zones will be sampled during pre-monsoon and postmonsoon. The three aquifer zones namely: Kailasa aquifer, Coastal aquifer and Marshy aquifer will be continuously monitored and samples will be analysed in the standard laboratories on continuous basis.

The results obtained will be subjected to special analysis using GIS software for the identification of zones of pollution or are zones of slightly pollution in future. This will be based on quality standards suggested by WHO, ICMR, etc. The computer output showing the quality variations will be displayed to all stakeholders time to time. (Fig-6) 
International Journal of Science and Research (IJSR)

ISSN (Online): 2319-7064

Index Copernicus Value (2013): 6.14 | Impact Factor (2015): 6.391

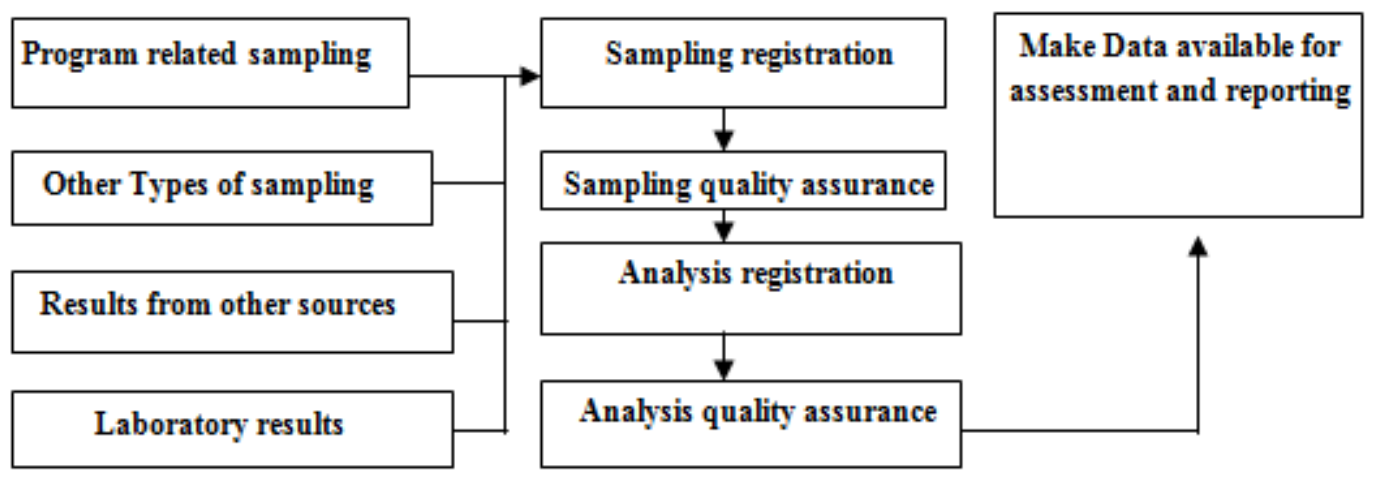

Figure 6: Data capture process

\section{Compliance Management}

In this module data related to pollution and areas which may be affected by future pollution will be monitored and procedures of compliance will be implemented. This includes:-

1) Identification of sources of polluting agents

2) Implementing waste standards and treatment standards to the industries so that the waste disposal is not harmful.

3) Implementation of strong legislative measures for the protection of ground water quality

4) Reporting the areas under compliance

5) Graphical display of the data for the benefit of the stakeholders including government and public.

The Following flow-sheet explains this concept (Fig-7)

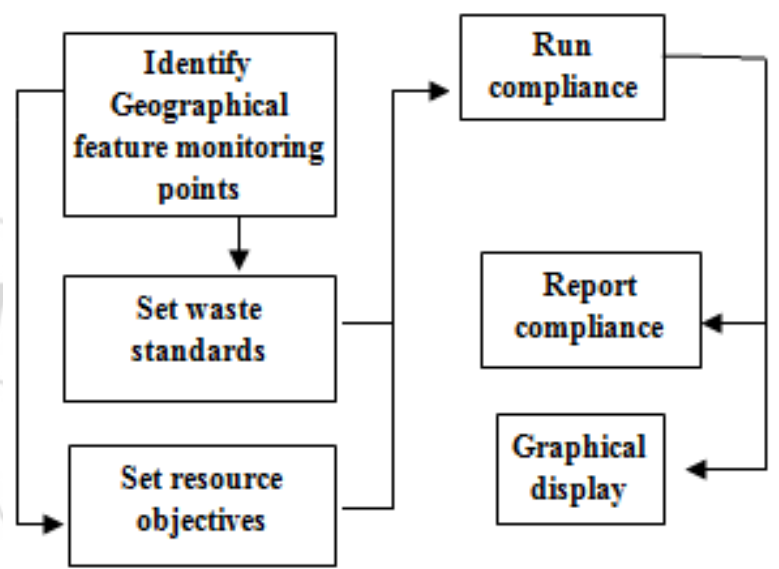

Figure 7: Compliance management

Reporting:

The data generated from the monitoring stations need to be displayed and reported in an effective manner. For this purpose, the statistical tools need to be used for analysing the data followed by display of the data in the form of graphs. The reporting of the data from time to time is one of the most important modules of ground water information system under study. The available tools of statistics and special data base format can be customized and applied as per our needs. It is to be remembered the output maps and reports should be such that the common man will be able to understand the reporting perfectly. (Fig-8)

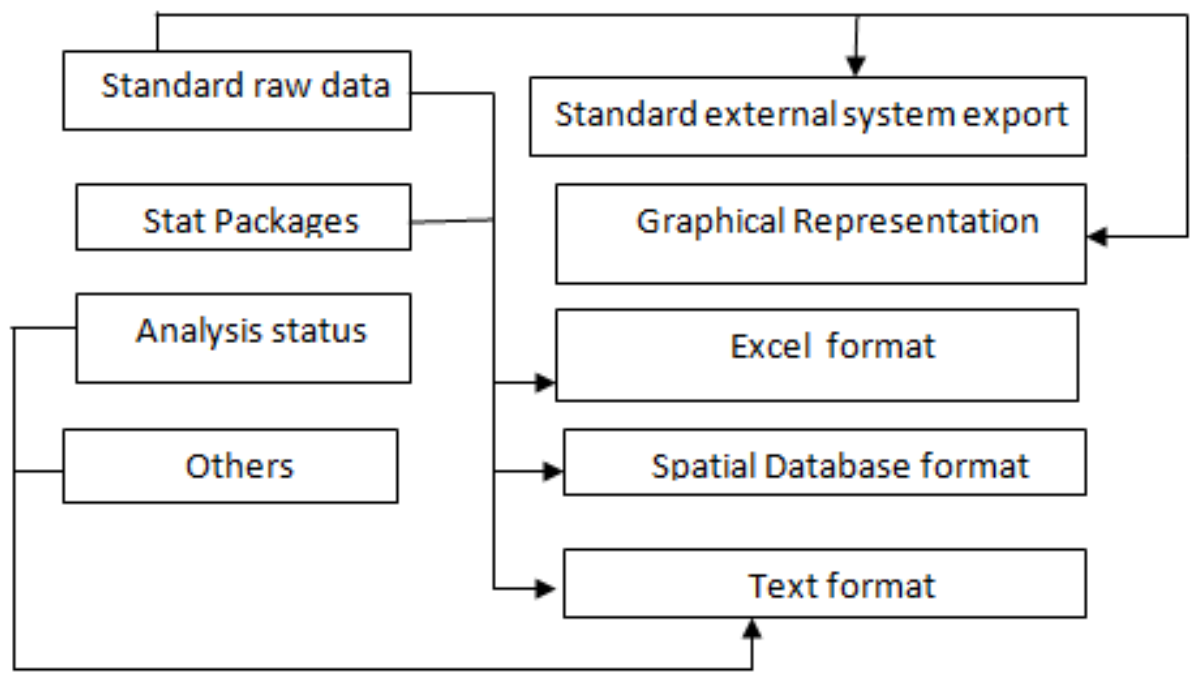

Figure 8: Reporting 


\section{International Journal of Science and Research (IJSR) \\ ISSN (Online): 2319-7064}

Index Copernicus Value (2013): 6.14 | Impact Factor (2015): 6.391

\section{Data Storage}

This is one of the important modules of the water management system. In this module options will be there for storage of the data using tools of multimedia. The archived data will be in the form of documents, slide shows, sound clips, video clips, references etc., Can be accessed by stakeholders at any point of time. The data storage will be taken care of with multiple backups. (Fig-9)

\section{Conclusion}

The groundwater information system (GWIS) designed and discussed above will have effective applicability on groundwater resource management. The integrated approach which includes groundwater resource recharge, groundwater resource protection, groundwater resource sustainable utilization, groundwater resource spatial database management. This integrated approach will help a given region for effective management of groundwater resources resulting conservation of the resources and protection from pollution, implementation of legislative measures, temporal and spatial database system for policy decision, etc.

The application of this system to an urban environment like Visakhapatnam has been indicated and its applicability tested such information system will help to conserve the groundwater resources and help in design of programs to ensure clean and sustainable groundwater resource. The available spatial database systems can be customized for suitability and can be used to other cities or urban centres.

\section{References}

[1] Anjaneyulu,B.J.N.S..R., 1950. The study of the black sand concentrates and geology of coastal strip from Analkapalle to Vizianagram, M.Sc. Thesis, Andhra University Waltair.

[2] Bhaskara Rao, V.U., and Vaidyanadhan, R., 1975. Photo Geomorphic study of coastal features between Visakhapatnam and Pudimadaka in Andhra Pradesh. Photonirvachak, 3(1), 43-46

[3] Jagannadha Rao, M, J.Syam Kumar, B. Surya prakasa Rao and P. Srinivasa Rao (2003) Geomorphology and land use pattern of Visakhapatnam Urban-Industrial area. Photonirvachak, Journal of the Indian Society of Remote Sensing, Vol. 31, No. 2, 2003

\section{Water network}

Stakeholders

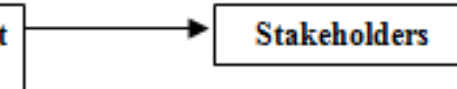

Mahadevan,C.\&Sathapathi, N.,1949.
Waltairhgh lands, Ind.Geogr.J.24,1-26.

[8] Natarajan, V.,Nanda. K, \&Subrahmanyam, M.R., 1979. Geology and its influence on physical environment of Visakhapatnam city and its neighbourhood. Paper presented in work shop on integrated resource evaluation for Visakhapatnam Urban growth center, 1.2, 1-10.

[9] Nooka Raju, D and Vaidyanadhan , R., 1971. Hill slope elements and surfacial deposits near Visakhapatnam, Andhra Pradesh, J of the Ind.Geol. Sci. Association, 13, 45-51.

[10] Shyam Kumar J (1995) Environmental Geology and Impact Assessment of two Geological subEnvironments from Visakhapatnam Urban-Industrial area. A.P. Unpublished Ph D thesis Andhra University.

[11] SrinivasaSastry, C., 1952. Geology of western part of Toposheet, 65 O/5.M.Sc.thesis,Andhra University, Waltair. 